\section{Afforestation and Scenery in Great Britain}

DURING the past few months, a number of letters and articles have appeared in the Press and in journals regarding the damaging effects of afforestation on the landscape of Britain. In some cases, the Forestry Commissioners have, rightly or wrongly, come in for adverse criticism on the ground of having desecrated some of England's beauty spots, notably in the Lake District, by planting serried ranks of conifers. We may assume that even the Forestry Commissioners have souls, and that they are not wholly devoid of the aesthetic sense; but they have a duty to perform to the nation, that of providing an adequate reserve of standing timber, and however great may be their desire to avoid any action which might seriously affect the beauty of the countryside, they cannot be expected to be entirely impartial judges in matters affecting their programme of work. Here there is more than one interest involved, and in cases where interests conflict, the wise thing is for the parties concerned to meet and come to a friendly agreement. We therefore welcome the announcement that the Forestry Commissioners and the Council for the Preservation of Rural England have set up a joint informal committee, which will meet from time to time and endeavour to come to an agreement in cases where their respective interests are likely to clash. It is hoped that this will be the means of maintaining the beauty of the country without seriously affecting the important work being carried out by the Forestry Commission.

\section{Holly Lodge Farm}

Aт a meeting on May 16 of the Select Committee of the House of Commons on Unopposed Bills, the Metropolitan Water Board Bill was considered. Under this Bill, it is sought to construct various new works, including a reservoir covering 417 acres in the Staines area and another about 374 acres in extent in the Walton and Weybridge area. This latter will involve submerging Mr. F. W. Secrett's Holly Lodge Farm (see NATuRE, February 2, p. 177, and February 9, p. 228). On behalf of the Metropolitan Water Board it was stated that the farm has been brought to a very high state of cultivation, chiefly by the use of artificial manures, and also due to the fact that the soil is of a certain consistency. It is not contended that there is no other soil in the country of the same physical consistency, or which could not be brought finally to an equal state of high cultivation. Indeed, if there were not, then this farm of 180 acres could not be considered to be of the slightest use to the nation. The arrangement is that the lessee of the farm shall remain in possession for at least two years, in order that, if he thinks fit to do so, he will have time to change to another farm on which he may carry on his very useful work. The Committee found the preamble of the Bill proved, and it was ordered to be reported for third reading.

\section{The Green Flash}

Since the appearance in NATURE of May 4 of the letter by Prof. Worley, with a brief comment by
Lord Rayleigh, on this subject, further correspondence has been received confirming the suggestion that "the green flash is by no means a rare phenomenon". Mr. H. Cary Gilson, Trinity College, Cambridge, states that he has observed the flash several times during the past five years from a point in Sussex $150 \mathrm{ft}$. above sea-level. In October 1933, while in the Gulf of Aden with the John Murray Expedition, "the flash could be clearly seen, with or without glasses, almost any evening", and was even observed from a port-hole about $18 \mathrm{in}$. above the water. $\mathrm{Mr}$. Northcote Thomas, Grove Cottage, West Malvern, Worcs, has sent a summary of observations made from the upper part of West Malvern, $800 \mathrm{ft}$. above sea-level. He states that a flash or similar phenomenon was seen on forty-one occasions between July 25, 1934, and April 20, 1935. The flash was green until about mid-September; blue or green from September 17 until October 8; blue from October 11 onwards. On occasions the colour persisted for half a minute. Previous volumes of NATURE will show that the green flash has already received considerable attention; and index entries to letters on the subject will be found in vols. 93-95, 110, 111, 120-123. The comparative frequency of the occurrence and the change of colour to blue were referred to, and also its appearance at sunrise as well as sunset. The weight of evidence, and particularly the sunrise effect, points to a physical explanation of the phenomenon, which is accepted by Prof. R. W. Wood in a letter in NATURE of March 31, 1928 (p. 501), where he suggests that the relative temperature of the atmosphere and the surface with which it is in contact is the determining factor; a cold surface with warm atmosphere would increase the normal gradient of refractive index, and also the curvature of the rays, so delaying 'sunset' and affording "greater opportunity for atmospheric dispersion to come into play".

\section{Memorial to the late Dr. W. C. Unwin}

$\mathrm{By}$ the older engineers of the present day, the late Prof. W. C. Unwin will be remembered as an outstanding figure in the fields of engineering education and the practical application of scientific principles to the needs of civil and mechanical engineers. In his long career, which covered the latter half of the last century and the first quarter of the present, he witnessed the greater part of the evolution of engineering as we know it to-day, and in all the branches of the profession with which he was more directly concerned he occupied a pre-eminent position. $\mathrm{He}$ died on March 17, 1933, aged ninety-four years; an appreciation of his life and work appeared in NATuRE of May 13, 1933 (p. 681). A representative committee, under the chairmanship of Sir Alfred Chatterton, of Unwin's friends and old students, supported by representatives of the Royal Society, the principal British and American engineering societies and of the educational organisations with which he was connected, has now been formed for the purpose of establishing a suitable memorial. The committee is endeavouring to raise funds for the founding of an Unwin scholarship at the City and 
Guilds (Engineering) College, of which Unwin was the first professor of civil and mechanical engineering and the first dean, and to publish a biographical memoir based upon the one which was published in the Unwin Memorial issue of the Central, the journal of the City and Guilds College Old Students' Association, and so make available a record which so far has only been published for private circulation. Fuller particulars of the Committee's proposal can be obtained from the joint honorary secretaries, Messrs. G. A. Hicks and J. Severs, c/o The Institution of Civil Engineers, Great George Street, S.W.1, and contributions to the fund should be sent to the honorary treasurer, Mr. E. G. Walker, 82 Victoria Street, London, S.W.1.

\section{Communications and the Manufacturer}

THE fourth of the "Green Papers" issued by the Post Office contains a lecture by E. S. Byng to the P.O. Telephone and Telegraph Society read on January 15, 1934. He points out that the outstanding success of telephone development in the United States is attributed in some measure to the close working arrangement between the operating andmanufacturing departments of the business. In the Bell system, the various operating companies and manufacturing associations are controlled by the American Telegraph and Telephone Co. In Great Britain, the State, as owner of the whole system, does not attempt to manufacture to any appreciable extent. The production of the necessary materials and plant is rightly entrusted to industrial companies. By mutual co-operation and understanding, the Post Office and the manufacturers should be able to operate in much the same way as a single organisation. Of recent years, after work has been begun on a contract, engineers rarely ask for changes to be incorporated. Inspection in a factory may be likened to a running commentary on manufacture, as the inspection includes observing, reporting and criticising. It varies from so little as 2 per cent to 100 per cent of the total goods manufactured. Some processes call for continual vigilance, while others have mechanical safeguards against inaccurate perform. ance. The telephone dial alone consists of nearly seventy 'piece' parts each of which must be checked for accuracy of forming and its dimensions gauged between the maximum and minimum limits. In succeeding stages, the tensions of the springs are measured, the dimensions to the thousandths of an inch and the speed of operation to thousandths of a second.

\section{A New Domestic Coke}

A REPORT issued by the Department of Scientific and Industrial Research (H.M. Stationery Office, $9 d$. net) records a test by the Director of Fuel Research on a plant erected by the British Coal Distillation Co., Ltd., at Newbold, Leics., and designed to prepare a smokeless fuel from an entirely non-coking coal, high in ash. The unwashed coal is first dried and passed through a revolving inclined retort, where it is carbonised at $600^{\circ} \mathrm{C}$. by hot products of combustion of producer gas. The residue from the retort is discharged into a trough of water, and the 'clean' coke, which floats, is skimmed off the surface, while the dirt sinks and after removal is used for fuel on the plant. The resultant 'clean' coke is made with pitch into briquettes, which are stored to give a domestic fuel. The throughput of the plant as claimed-100 tons per day-was substantially confirmed, giving a fuel which was considered satisfactory for the open grate, a notable achievement for such a raw material. This is a technical test made in accordance with the normal practice of the Department, and does not purport to give an opinion about the commercial success of the process.

\section{Journal of the Royal Horticultural Society}

WIтH the publication of vol. 49, Part 3, in September 1934, the Journal of the Royal Horticultural Society became a useful and informative monthly publication instead of a quarterly or half-yearly volume. The change should be welcome to all concerned, and certainly it will enable the Society to inform members of its activities more efficiently. Lord Aberconway, president of the Society, outlined the main features of the change in the September issue. The Journal has maintained a high standard. of learning, science and practice for nearly fifty years, and has grown from a tiny circulation to a very large one. The new arrangement is designed "to add rather than to replace. ... Records will be more up-to-date; news can be given while it is still fresh; information of coming events can be made available; notes of more immediate interest can be introduced; the most recent information as to the Society's activities at Wisley can be included". The "Book of Arrangements" will no longer be issued, but the information will be included in the January and February numbers of the Journal. The parts which have appeared since the change was effected show that the standard is even higher, if that is possible, than of old, whilst the total volume of subject-matter seems to have increased.

\section{National Research Council, Canada}

ThE seventeenth annual report, for 1933-34, of the National Research Council of Canada, in addition to reviewing the researches on analysis and testing conducted in the National Research Laboratories, gives a summary of the activities of associate committees and of assisted researches in university and other laboratories and under scholarships. A financial statement is included, together with particulars of the personnel of the varjous research, advisory and special committees. Among the researches completed in the National Research Laboratories during the year may be mentioned investigations on the suitability of Canadian clays for oil-refining, the bonding of rubber to metal, the chemical investigation of Canadian weeds poisonous to livestock, the suitability of Canadian wools for the manufacture of cloth, the causes of premature seeding in turnips, the stability of aircraft floats and the correction of instability in aircraft used for photographic survey work. Researches conducted under associate committees have dealt with methods for combating losses due to 